\title{
Barbara FALIŃSKA
}

Warszawa

\section{NOWOCZESNE OPRACOWANIE ROSYJSKIEGO SŁOWNICTWA GWAROWEGO}

Trzecie tysiąclecie $w$ dialektologii rosyjskiej rozpoczęło się wielkim osiągnięciem. Po wielu latach oczekiwania slawiści otrzymali wspaniały prezent w postaci próbnego tomu Atlasu leksykalnego rosyjskich gwar ludowych ${ }^{1}$, wydanego w roku 2004 przez Instytut Badań Lingwistycznych i Instytut Słowianoznawstwa Rosyjskiej Akademii Nauk. Jest to dzieło imponujące zarówno ze względu na treść, jak i na formę. Mapy, wykonane w skali 1:5000 000, wydane są w kolorach na papierze offsetowym o formacie $64 \times 84$. Tekst podany w sposób przejrzysty, bardzo czytelny. Całość w pięknej oprawie.

Mimo tak starannego wydania, tom ma charakter próbny. Rozpoczyna serię wielotomową, która jest w stadium zaawansowanego opracowywania, dającego jeszcze możliwości wprowadzania ewentualnych uściśleń lub uzupełnień materiałowych. Atlas po raz pierwszy obejmie największy ze zbadanych dotychczas zakres leksyki, zaświadczonej na całym obszarze Rosji europejskiej od Białego do Czarnego Morza, a na wschodzie do Uralu. Mapy zakwalifikowane do tomu zostały wybrane $\mathrm{z}$ kręgu tematycznego: Leksyka przyrody. Przy ich doborze kierowano się założeniem, że każdy podstawowy typ zróżnicowania geograficznego powinien być w tym tomie reprezentowany. Mapy informują o słowach lub stałych związkach wyrazowych jako elementach systemu leksykalnego gwar, o ich zróżnicowaniu znaczeniowym i strukturalnym.

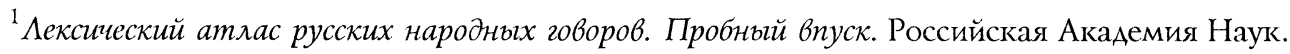
Институт кингвистических Исследований. Институт Славяноведения. Ответственные реАакторы: И. А. Попов, Т. И. Вендина. Санкт-Петербург. Издательство <Наука >, 2004, 304 с; 36 карт.

Dalej posługuję się skrótem Atlas, zarówno w odniesieniu do tomu recenzowanego, jak i do całego zamierzonego wydawnictwa.
} 
W opracowywaniu tomu próbnego uczestniczyły - poza wymienionymi wyżej Instytutami RAN - 54 wuzy $^{2}$, tj. szkoły wyższe, głównie o kierunku pedagogicznym (44 uniwersytety, 18 instytutów, 2 inne uczelnie). Struktura tomu przedstawia się następująco: $w$ części I po słowie wstępnym podane są informacje dotyczące historii prac nad Atlasem (przebieg badań terenowych, bibliografia ważniejszych artykułów, opublikowanych w seryjnym wydawnictwie Atlas leksykalny rosyjskich gwar ludowych. Materiały $i$ badania, ${ }^{3}$ materiały kartotek gwarowych według regionów, spis miejscowości uwzględnionych w Atlasie i rejonizacja badanego obszaru; część II stanowią mapy; w części III zamieszczony jest indeks zmapowanych nazw, spis rejonów, w których była badana leksyka dotycząca przyrody, kwestionariusz do badań rosyjskiej leksyki gwarowej z przeznaczeniem dla Atlasu.

Tom kończy się artykułem poświęconym pamięci inicjatora, współautora i głównego redaktora w pierwszym okresie prac - I. A. Popowa.

Ze wszystkich możliwych form ekspozycji materiałów gwarowych, atlasy są najcenniejszym źródłem informacji, choć metoda ich opracowywania nie jest sprawą prostą. Liczą się pomysły, ale przede wszystkim liczy się doświadczenie, zwłaszcza w dzisiejszych czasach, gdy technika elektroniczna przychodzi dialektologom $z$ nieoczekiwaną pomocą i prowokuje do poszukiwania wciąż nowych rozwiązań, lepszych tak pod względem formalnym, jak i merytorycznym. Techniczna możliwość dokładniejszego eksponowania materiałów, przy zachowaniu dobrej czytelności mapy, pozwala na rozszerzanie zakresu interpretacji mapowanych faktów. Jeszcze przed kilkunastu laty mapy do Ogólnostowiańskiego atlasu językowego (dalej: OLA) ${ }^{4}$ rysowaliśmy długopisami za pomocą tzw. linijki oficerskiej, a dziś program komputerowy nanosi najbardziej skomplikowane znaki na mapę automatycznie. Może przy tym różnicować ich wielkość w miarę potrzeby, może je zamieniać na szrafurę, płaszczyznę lub izoglosy, może kopiować, a następnie zmieniać każdą mapę tyle razy, ile wariantów jej treści zaprogramuje autor. Dzisiaj można więc już myśleć o bardzo skomplikowanych mapach zbiorczych, uogólniających obrazy pojedynczych map w taki sposób, aby przedstawiały zasięgi terytorialne $\mathrm{w}$ ujęciu systemowym na różnych płaszczyznach chronologicznych.

Zespół zajmujący się m.in. kartografowaniem leksyki Podlasia i Suwalszczyzny śledzi z uwagą każde atlasowe osiagnnięcie słowiańskie, toteż recenzowany tom jest dla nas szczególnie cenną lekturą. Korzystamy z niej podwójnie: porów-

\footnotetext{
2 'высшее учебное заведение'

${ }^{3}$ Аексический атлас русских народных говоров: Материаль и исследования 1992 (СПб., 1994) i nn.

${ }^{4}$ OLA = skrót nazwy rosyjskiej: Общеславянский лингвистический атлас. Por. też Вступительный выпуск. Общие принципы. Справочные материалы, Москва 1978.
} 
nawczo, jeśli idzie o powiązanie i zasięgi przewidzianych do mapowania faktów; metodologicznie zaś - jeśli idzie o ustalenie hierarchii w systemie znaków, pozwalających odróżniać „bohaterów” map od zagadnień traktowanych podrzędnie ze względu na ich mniejszy stopień ważności dla danego kartogramu. Poza zagadnieniami teoretycznymi i technicznymi, bliska jest nam także współpraca dialektologów z nieprofesjonalistami. Możemy się podpisać pod stwierdzeniem wyrażonym przez autorów na s. 17: Wydaje się, że dzisiaj nasz dług, dług lingwistów, wobec ojczystej kultury i nauki polega - nie w ostatniej kolejności - i na tym, żeby po ziarenku od regionu do regionu zebrać wszystko to, co żyje jeszcze w pamięci ludowej, co zachowało się w rosyjskiej ludowej mowie. Nam waszych badaniach również przyświeca ta myśl.

Po śmierci I. A. Popowa, redakcję Atlasu objęła Tatjana I. Wendina, dialektolog z gruntowną wiedzą i z bogatym doświadczeniem, uzyskanym poza własnymi badaniami $\mathrm{w}$ toku wieloletniej współpracy $\mathrm{z}$ Międzynarodową Komisją OLA, której od kilku lat przewodniczy jako współautor i redaktor. Jej autorstwa jest obszerny artykuł wstępny, liczący 11 stron formatu atlasowego. Poświęciła go pamięci swojego mistrza - Nikity lljicza Tołstoja, współtwórcy nowoczesnej dialektologii rosyjskiej.

Wstęp czyta się $\mathrm{z}$ wielkim zainteresowaniem. Jest $\mathrm{w}$ nim wiele informacji o trudnym przebijaniu się problematyki leksykalnej i słowotwórczej przez poglądy osób decydujących o kierunkach w rozwoju dialektologii. Chcę je dokładniej przybliżyć dialektologom pracującym nad gwarami Podlasia, mając na uwadze brak dialektologii porównawczej w programie studiów polonistycznych. Oryginalne tytuły publikacji (przytaczane w przypisach) i cytowane wypowiedzi podaję za T. I. Wendiną.

Pomysł opracowania Atlasu powstał w latach 70. na posiedzeniu Komisji OLA w Leningradzie. Zgłosił go I. A. Popow w wykładzie uzasadniającym konieczność geograficznego opracowania leksyki. Ówczesna dialektologia rosyjska miała w tej dziedzinie nauki wiedzę przypadkową i należało się zatroszczyć o jej rozwój. Mimo to z przyczyn pozalingwistycznych realizacja idei Popowa opóźniła się o przeszło 20 lat, chociaż już w roku 1974 został opublikowany projekt Atlasu, podsumowujący dyskusję nad podstawowymi zagadnieniami związanymi z Atlasem, jak leksyka w słownikach gwarowych, dotychczasowe doświadczenia kartograficzne, teoretyczne założenia Atlasu, program i metody badań terenowych, źródła materiałowe, ramy chronologiczne, granice terytorialne i siatka punktów, transkrypcja, organizacja pracy i inne problemy. Przez okres oczekiwania na akceptację zamierzenia w rozwoju gwar nastąpiło wiele zmian, niekorzyst- 
nych z punktu widzenia badaczy. Zanikły pewne cechy gwarowe, odeszło wielu wspaniałych informatorów i utalentowanych dialektologów, destabilizacja norm dialektalnych pod wpływem języka literackiego nabierała tempa. Tymczasem zainteresowanie słownictwem gwarowym miało w Rosji tradycję dość dawną. Już bowiem M. B. Łomonosow - jak czytamy we Wstępie - zaczął tworzyć Leksykon rosyjskich prymitywów, tj. rdzennych lub pierwotnych słów języka rosyjskiego. Zainteresowania te nie wyszły jednak poza granicę etnograficznego poszukiwania archaicznych osobliwości. Trzeba było jeszcze czekać wiele lat, aż dialektologia oddzieli się od etnografii i stanie się samodzielną dyscypliną naukową. Zaczęto dostrzegać w dialektach żywotność słów, dawno nieobecnych w języku ogólnym, i wiązać je $z$ historią języka. Stopniowo budziła się świadomość głębokiej więzi tych słów $z$ „duchem narodu”, z tradycyjną kulturą ludową. A. N. Afanasjew, wielki znawca słowiańskiej starożytności, w połowie XIX w. pisał: „Słowniki regionalne przechowują mnóstwo starodawnych form i wyrażeń, które są tak samo ważne dla gramatyki historycznej, jak i dla dialektologii. (...) bez dokładnego zbadania prowincjonalnych cech języka, liczne zjawiska w historii ludowych wierzeń i obyczajów pozostaną ciemne i nieodgadnione" - jak stwierdzał uczony rumuński J. Jordan - czołowe miejsce zajmowały również zagadnienia fonetyczne, na drugim planie były formy gramatyczne, na kolejnym - konstrukcje składniowe. Dla słownictwa i słowotwórstwa brak było jeszcze zrozumienia.

Kiedy dialektolodzy rosyjscy pracowali jeszcze nad mapą dialektów języka rosyjskiego (opublikowaną w 1915 roku), w szkołach zachodnioeuropejskich (niemieckiej, francuskiej i szwajcarskiej) powstawały już atlasy. Ale i w tych, i w późniejszych atlasach słowiańskich leksyka i słowotwórstwo wciąż jeszcze były niedoceniane. Zmiany dokonywały się stopniowo. Najpierw zaczęła zwyciężać nominacja. Badania terenowe prowadzono metodą onomazjologiczną - od desygnatu do słowa. Pytania o znaczenie poszczególnych słów pojawiały się rzadko lub sporadycznie, podobnie jak pytania dotyczące zróżnicowania strukturalnego nazw lub funkcji sufiksów. Rozwój dialektologii rosyjskiej utrudniały teorie polityczne, zakładające, że w społeczeństwie bezklasowym nie może być mowy o istnieniu dialektów, uzasadniane m.in. przez Stalina (Marksizm a zagadnienia językoznawstwa), że „ich zanik jest już faktem dokonanym”. Zaprzeczeniem tej teorii były prace dialektologów, podjęte w połowie lat $40^{5}$. Poprawa sytuacji nastąpiła dzięki opracowaniu dyferencjalnego Stownika rosyjskich gwar ludowych ${ }^{6}$, obejmującego słownictwo poświadczone w źródłach od początku XIX do połowy XX wie-

\footnotetext{
${ }^{5}$ Por. Prograтmа собирания сведений для составления диалектологиеского атласа русскогоя зыка Ярослав, 1945; Атлас русских народных говоров чентральных областей к востоку от Москвы, реА. Р. И. Аванесов, Москва 1957.

${ }^{6}$ Словарь русских народньх говоров, Вып. 1-37. М.; А. (СПб.), 1965-2003.
} 
ku. Publikowanie słownika, rozpoczęte w latach 60. mimo niepełnej reprezentacji rosyjskiego obszaru, ukazało specyfikę semantyczno-słowotwórczą nazw gwarowych i wynikającą stąd konieczność prowadzenia badań metodami geografii lingwistycznej. Dla potwierdzenia tych wniosków autorka wskazuje na doświadczenia słowackie: Atlas slovenského jazyka ${ }^{7}$, i polskie: Atlas językowy kaszubszczyzny i dialektów sasiednich ${ }^{8}$, A. Kowalska, Zróżnicowanie stowotwórcze gwar Mazowsza i Podlasia. Atlas ${ }^{9}$.

Leksykologia gwarowa powiązana $\mathrm{z}$ metodą geografii lingwistycznej nie od razu w dialektologii rosyjskiej utorowała sobie drogę, choć już w 1949 roku ukazał się Atlas lingwistyczny rejonu jeziora Seliger M. D. Malcewa i F. P. Filina ${ }^{10}$, zawierający 45 map, w tym 15 poświęconych leksyce. „Nam w przytłaczającej większości wypadków jeszcze nie znane są granice rozprzestrzenienia słów gwarowych, ich izoglosy, chociaż mamy już wiele danych, aby z większą lub mniejszą pewnością odróżniać słowa dialektalne od ogólnorosyjskich” - czytamy we Wstępie cytowaną wypowiedź F. P. Filina z lat 60., ale jak pisze autorka Wstępu, przez prawie 40 lat niewiele się zmieniło. $\mathrm{Na} 250$ tysięcy słów gwarowych (według danych wynikających $z$ ekscerpcji regionalnych kartotek i słowników gwarowych) zaledwie $1 \%$ nazw opracowano geograficznie ${ }^{11}$. W tej sytuacji opracowanie gwarowej leksyki w formie Atlasu stało się najpilniejszym zadaniem dialektologii rosyjskiej. Szybkie przemiany ekonomiczno-kulturowe uświadamiają dialektologom, że czas dokumentowania najstarszej odmiany języka narodowego jest $\mathrm{z}$ każdym dniem coraz bardziej ograniczony. Od postępu w badaniach terenowych leksyki zależy także ustalenie udziału poszczególnych regionów w kształtowaniu się rosyjskiego języka literackiego, opierane dotychczas głównie na faktach fonetycznych i morfologicznych. Znajomość ugrupowania dialektów w świetle leksyki jest też niezbędna przy wyjaśnianiu problemów etnogenezy czy dyferencjacji plemiennej w grupie wschodniosłowiańskiej. Leksykolodzy rosyjscy, zainspirowani polskimi opracowaniami z serii: Stownictwo Warmii i Mazur ${ }^{12}$, przeprowadzili próbę uzupełnienia Pskowskiego słownika regionalnego ${ }^{13}$ mapami słownictwa gwarowego, ale po opracowaniu I i II tomu zrezygnowano z tej metody. Konieczność opracowania Atlasu stawała się coraz bardziej widoczna. Podkreślały ją intensywnie rozwijające się prace dialektologów białoruskich i ukraińskich. Białorusini nie

\footnotetext{
${ }^{7}$ Bratysława 1968-84, por. t. III i IV.

${ }^{8}$ T. I-XV, Wrocław 1964-1978, por. tomy VII-IX.

${ }^{9}$ T. I-II, Wrocław 1975.

${ }^{10}$ АингВистический атлас района озера Селигер, М. А. Малыев и Ф. П. Филин А., 1949.

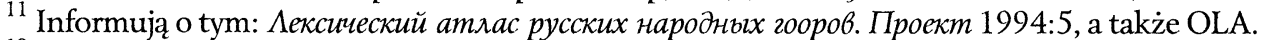

${ }^{12}$ Red. W. Doroszewski, Wrocław 1958 i nn.

${ }^{13}$ Псковской областной словарь, 1967.
} 
poprzestali na opublikowaniu Atlasu dialektologicznego języka białoruskiego ${ }^{14}$, opracowali serię słowników regionalnych, obejmującą wszystkie białoruskie dialekty, a następnie w latach 1993-1998 wydali Atlas leksykalny białoruskich gwar ludowych ${ }^{15}$. Na Ukrainie w 1984 r. ukazał się program zbierania materiałów do Atlasu leksykalnego ukrainskiej mowy, opracowany przez I. A. Dzendzelewskiego z Użgorodu ${ }^{16}$.

Prace dialektologów rosyjskich koncentrowały się w tym czasie nad Atlasem rosyjskich gwar ludowych ${ }^{17}$, w którym dział leksyki objął odpowiedzi gwarowe zaledwie na 102 pytania leksykalne i 52 semantyczne. W pierwszej części III tomu zamieszczono tylko 75 map. Informowały one o zróżnicowaniu geograficznym nazw odnoszących się do fragmentarycznie reprezentowanych działów kultury materialnej, takich jak: budownictwo, sprzęty domowe, odzież, pożywienie, rolnictwo, ogrodnictwo i hodowla.

Pod koniec XX wieku ukazały się pierwsze atlasowe opracowania regionalne: Atlas leksykalny rejonu moskiewskiego ${ }^{18}$ A. F. Wojtenko (1991) i Atlas leksykalny rejonu archangielskiego Ł. P. Komjaginoj (1994). Do obu tych atlasów włączano zagadnienia w sposób tradycyjny, wybiórczy, sięgający korzeniami do okresu, w którym dialekty były traktowane jako zepsuty język literacki.

Nową metodę kartografowania w latach 60 . przedstawił N. I. Tołstoj ${ }^{19}$, uzasadniając sens mapowania pól semantycznych. Przemyślenia tego wielkiego uczonego zbiegły się w czasie z pracami nad Ogólnosłowiańskim atlasem językowym i Atlasem karpackim ${ }^{20}$.

Kartografowanie leksyki i słowotwórstwa w tych dziełach było przedmiotem dyskusji na wielu międzynarodowych konferencjach. Ta sama problematyka była treścią map w Atlasie językowym Europy. Z każdą mapą wiązały się nowe doświadczenia, które potwierdzały ogromny pożytek z opracowywania leksyki i słowotwórstwa metodą kartograficzną. Aby jednak leksykologia i geografia lingwistyczna mogła dobrze wypełniać swoje zadania, nie może się ograniczać do tradycyjnego, wybiórczego sposobu opracowywania programów badawczych, nie może pomijać wyrazów zgodnych z językiem literackim, aby nie zachwiać relacji konstytuujących system badanego dialektu. Musi - za pomocą jednolicie zredagowanych ankiet - dążyć do uzyskania takich zbiorów słownikowych, które po-

\footnotetext{
${ }^{14}$ Аьлялекталагічны атлас беларускай мовы, Минск 1963.

${ }^{15}$ Аексічны атлас беларускіх народных гаворак: В 5 Мінск, 1993-1998.

${ }^{16}$ Програма для збирання матеріалів до Аексичного атласу української мови, 1984.

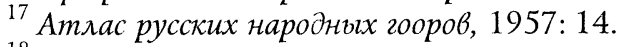

${ }_{18}$ A. F. Wojtenko, Һексический атлас Московской области, 1991.

19 Por. B. Falińska, Semantyka a geografia lingwistyczna. „Polonica” II, IJP PAN Kraków, 1976, s. 221-231.

${ }_{20}$ Общекарпацкий лингвистический атлас. Вступительный выпуск. Скопје 1987.
} 
zwolą - przez wykorzystanie metody kartografii lingwistycznej - na badanie leksyki i semantyki gwarowej, a także słowotwórstwa gwarowego jako swoistego systemu.

Jest rzeczą oczywistą, że wartość naukowa każdego atlasu pozostaje w bezpośrednim związku ze sposobem przeprowadzenia eksploracji materiałów w terenie, jak również z programami badań, które są zależne od celów stawianych sobie przez redaktorów, od możliwości kadrowych i finansowych, ale przede wszystkim od założeń teoretycznych. Programowanie kwestionariusza lub słownika zawsze wywołuje problem dyferencjalnego czy pełnego opracowania zamierzonej publikacji. W Polsce dominował typ pierwszy, uzasadniany zazwyczaj warunkami ekonomicznymi, ale też i niedostrzeganiem celowości wychodzenia poza słownictwo dyferencjalne. Kwestionariusz do badań słownictwa ludowego, opracowany pod kierunkiem W. Doroszewskiego, nastawiony był na uwzględnienie możliwie wszystkich desygnatów związanych z poszczególnymi działami kultury, niezależnie od regionalnego czy ogólnopolskiego zasięgu nazw. Taki też charakter miały późniejsze monografie, zawierające komentarze uzupełniane częścią atlasową, idące w kierunku bardziej systemowego traktowania badań słowotwórczo-semantycznych ${ }^{21}$.

Ten problem w artykule wstępnym T. I. Wendiny i w Jej przemyśleniach związanych z koncepcją Atlasu zajmuje szczególnie dużo miejsca. Włożyła Ona wiele trudu nie tylko w problemową, ale i w kartograficzną koncepcję tomu. Wprawdzie komputerowa wersja Atlasu powstała w Uniwersytecie Geodezji i Kartografii na podstawie programu MAPINFO, ale algorytm kartograficznego programu i system znaków jest Jej autorstwa.

Atlas leksykalny rosyjskich gwar ludowych będzie dziełem najobszerniejszym ze wszystkich dotychczasowych atlasów słowiańskich, łącznie z atlasem ogólnosłowiańskim. Badania na samym obszarze rosyjskim przeprowadzono w 1064 wsiach, podczas gdy w siatce ogólnosłowiańskiej do OLA jest ich tylko 853. Pełen program badań, obejmujący ponad 5000 pytań dotyczących leksyki, i projekt Atlasu po wielu dyskusjach naukowych, przeprowadzonych w szerokim gronie dialektologów pod kierownictwem I. A. Popowa, opublikowano już w 1994 r. Przyjęto systemowe podejście do badań leksykalno-słowotwórczo-semantycz-

${ }^{21}$ Por. I. Szczepankowska, Z problemów systemowego opisu leksyki dialektów polskich, [w:] Witold Doroszewski. Mistrz i Nauczyciel, red. B. Falińska, Łomża 1997, s. 221-225. Problemy stowotwórcze $w$ badaniach leksyki dialektalnej, [w:] Tradycja badań dialektologicznych $w$ Polsce, red. H. Sędziak, Olsztyn 1997, s. 134-139. 
nych, możliwe do realizacji dzięki odpowiedniej koncepcji badań, umożliwiających analizę pełnych układów relacji formalnych i znaczeniowych.

Pierwszym zadaniem autora mapy jest bardzo wnikliwa analiza materiału słownikowego, jaki ma on do dyspozycji i ustalenie zagadnień przewidywanych do wyeksponowania na mapie. Kolejna czynność polega na przygotowaniu zbiorczego indeksu materiałów, obejmującego nazwy danego desygnatu i ich zleksykalizowane warianty fonetyczne lub morfonologiczne wraz z numerami wsi, w których zostały poświadczone. Analiza odpowiedzi uzyskanych w terenie i nazw wyekscerpowanych ze źródeł publikowanych powinna dać wstępną orientację, czy są one wystarczająco zróżnicowane geograficznie, aby należało poświęcić im mapę. Dopiero takie przygotowanie pozwoli zająć się podziałem informacji między mapę i komentarz, a następnie zaprogramowaniem symboli kartograficznych, zhierarchizowanych i usystematyzowanych odpowiednio, to znaczy w sposób zapewniający dobrą czytelność mapy. Do tego celu służy z jednej strony technika kartograficzna, ułatwiająca dobór znaków i wykonywanie odrębnych map dla poszczególnych typów zjawisk językowych, jeśli zaistnieje taka konieczność, $z$ drugiej strony zaś komentarz autorski, w którym $\mathrm{z}$ reguły zamieszczane są nazwy sporadyczne (poświadczone tylko w jednym punkcie) i omawiane wszelkie uściślenia znaczeniowe czy modyfikacje założeń formalnych.

Mapy drukowane są techniką kolorową, na specjalnym papierze, tylko po jednej stronie. Na legendę przeznaczono miejsce w prawym dolnym rogu. Wypełnia je: tytuł mapy, rozpoczynający się od sygnatury literowej oznaczającej typ mapy, numeru pytania kwestionariusza, nazwy literackiej desygnatu lub definicji opisowej i wykazu mapowanych nazw, formantów lub rdzeni. Mapowane nazwy podawane są w pisowni literackiej z zaznaczeniem akcentu. Legenda bywa zazwyczaj uzupełniona jedną, dwiema lub trzema dodatkowymi informacjami. Pozioma kreska $\mathrm{z}$ lewej strony numeru wsi oznacza brak poszukiwanej odpowiedzi, tylda po prawej stronie numeru w górnej frakcji odsyła do materiału, a gwiazdka zamiast niej-do komentarza. W lewym dolnym rogu podane jest nazwisko autora mapy, komentarza i indeksu materiałowego. Nad górną ramką mapy z lewej strony wymieniony jest tytuł Atlasu, a z prawej - jej numer. Opracowywaniu map towarzyszyła ponowna dyskusja, rewidująca i uściślająca teoretyczne założenia i koncepcję kartograficzną Atlasu, a także oceniająca przyjęte w nim metody mapowania. Od 1990 roku prowadzone są seminaria kartograficzne dla współautorów Atlasu.

Druga strona mapy nie mogła być wykorzystana (jak w OLA) na druk komentarzy i materiałów nie tylko przez wzgląd na szczególny rodzaj papieru, ale i przez objętość tekstu uzupełniającego, zajmującą średnio pięć stron. W OLA 
wystarczyła odwrotna strona poprzedniej mapy. W omawianym tomie zamieszczono je w dalszej kolejności, bezpośrednio po mapach, nie podając, niestety, numerów map, co bardzo utrudnia porównywanie. Schemat tekstu związanego z mapą przedstawia się następująco: a) tytuł mapy (powinien być także i numer mapy, łatwiej byłoby ją odszukać), b) komentarz, c) ilustracje (o charakterze cytatów słownikowych, zaczerpnięte $\mathrm{z}$ relacji informatorów, pochodzących nawet z 20 miejscowości, podane w pisowni ortograficznej, uwzględniającej różnice morfologiczne, fonetykę zleksykalizowaną i akcent), zbiorczy alfabetyczny spis mapowanych słów z przytoczeniem kolejnych numerów wsi, w których zostały one udokumentowane.

Część komentarzowo-materiałowa dopełniona jest spisem miejscowości $\mathrm{z}$ odpowiadającymi im numerami, z nazwami rejonów, z podaniem dat i organizacji biorących udział w badaniach gwaroznawczych związanych z leksyką przyrody.

Gruntowna analiza branego pod uwagę materiału leksykalnego pozwoliła autorom na wyodrębnienie aż 11 typów map, z których tylko kilka występuje w tomie próbnym. Omówię je w kolejności przyjętej w Atlasie, bez szczegółowej analizy treści map i komentarzy.

1. Mapy leksykalne - (10 map) opracowywane są na podstawie materiałów zebranych metodą onomazjologiczną, od znaczenia do słowa. Przedmiotem kartografowania w tym typie map są nazwy jednego i tego samego desygnatu, którym może być rzecz, czynność, cecha, zjawisko lub relacja. Główny podział tworzą nazwy o różnej etymologii. Im większy obszar, tym mniej czystych podziałów etymologicznych. O typie map decydują zasięgi geograficzne nazw powszechnych lub częstych. Warianty słowotwórcze, które im zazwyczaj towarzyszą, są nieliczne, rozproszone, bez znaczenia dla podziałów terytorialnych. Nazwy poświadczone jednokrotnie nie są nanoszone na mapy. Wymienia się je w komentarzach do map razem z numerami miejscowości (np. na mapie 1: wywjurka 959, oresznica 815). Wśród tych nazw bywają archaizmy, neologizmy, nazwy przejęte z języka literackiego lub z obszarów pogranicznych. W komentarzach przewidziane jest również miejsce na informacje o nazwach różniących się desygnatów, występujących w materiałach terenowych (np. biełka n.o., bielczycha 'nazwa samicy'). Bardzo ważne są uwagi etnograficzne i materiał ilustracyjny. Np. nazwa biełka oznaczała pierwotnie 'biały gatunek wiewiórek'. Dziś jest rozpowszechniona w znaczeniu ogólnym, może być zleksykalizowana lub nie: Bietka koriczniewa, a weksza takaja że, tolko z łysinkoj, wot tut, kak u kota (274). Biełka biełaja, ona nie biegajet po derewam. A weksza krasnaja, biegajet po derewam (123). Wielkość komentarzy 
i liczba przykładów jest zależna od stopnia zróżnicowania zapisów terenowych, komplikacji etymologiczno-etnograficznych i inwencji intelektualnej autora.

Wykaz map: 1) L 218 wiewiórka (nazwa ogólna, dalej: n.o.); 2) L 217 barłóg, legowisko; 8) L 178 dzikie zwierzę, zwierz ( n. o.); 10) L 210 'wydawać głośne dźwięki, charakterystyczne dla dzikiej świni’; 14) L 211 'wydawać głośne dźwięki, charakterystyczne dla lisa'; 21) L 188 niedźwiedź; 23) L 379 drobna ryba (n. o.); 31) L 216 'nora niewielkiego zwierza'; 35) L 212 tchórz; 36) L 173 pieczarka.

2. Mapy leksykalno-etnograficzne ( 1 mapa). Ich podstawą są materiały gromadzone tak jak do map leksykalnych, metodą od znaczenia do słowa, uwzględniające informacje etnograficzne, wyrażane przez tło mapy lub przez izopragmy (termin etnograficzny, będący w opozycji do izoglos), a za pomocą znaków zostanie wyrażone zróżnicowanie językowe. Typ ten ilustrowany jest w tomie próbnym przez mapę 34) 'typy stodół i ich nazwy', łączącą odpowiedzi na 2 pytania kwestionariusza: Sł 16 333, 16334 (dwie pierwsze cyfry (16) oznaczają dział kwestionariusza).

3. Mapy semantyczne - (2 mapy). Materiał zebrany metodą semazjologiczną, od słowa do znaczenia. Mapa może przedstawiać zróżnicowanie znaczeniowe jednego i tego samego słowa lub w wypadku homonimów - zasięgi znaczeń słów mających tę samą formę dźwiękową. Mapy 3) i 4) Sm 187 'wilk samotnik'.

4. Mapy leksykalno-semantyczne - pokazują strukturalne i przestrzenne powiązania między różnymi słowami odnoszącymi się do takich desygnatów, których nazwy występują w częściowych systemach dialektalnych, powiązane są paradygmatycznie i tworzą leksykalno-semantyczne czy strukturalnosemantyczne grupy lub ich fragmenty. Badania prowadzone metodą od słowa do znaczenia. Mapowane są odpowiedzi na to samo pytanie, między którymi mogą wystąpić różnice znaczeniowe, jeśli występujące obocznie nazwy znajdą się w tym samym dialekcie. Przewidywana jest większa liczba map tego typu.

5. Mapy słowotwórcze - (1 mapa). Mapy leksykalno-słowotwórcze (24 mapy). Wśród map typowo słowotwórczych wyodrębniono siedem podtypów: a) zasięgi morfemu słowotwórczego i jego wariantów, np. rzeczownikowe sufiksy $-n j a g / n j a k$, njog/njok w nazwach zbiorczych, b) zasięgi derywatów z tym samym formantem w określonej funkcji znaczeniowej, np. np. sufiks -ixa ze znaczeniem 'żeńskości' (doktoricha, gusicha, medwiedicha) lub z odniesieniem do tematu podstawowego (żetticha 'ziemia nieurodzajna', c) zasięgi derywatów tworzących grupę leksykalną z tym samym formantem, np. z sufiksem -ika (np. wesznika 'wiosenne runo owcy', gustika 'gęsta zupa, kasza', d) zbiorcze mapy słowotwórcze modeli poszczególnych grup leksykalno-semantycznych, nie uzupełnianych już nowymi nazwami, np. nazwy jagód jadalnych, dziko rosnących, e) zbiorcze mapy słowotwórcze typów derywatów $z$ jednakowym, częściowo 
zmodyfikowanym znaczeniem, np. znaczenie 'żeńskości' lub 'zbiorowości', f) mapy przedstawiające rozmieszczenie nazw utworzonych od podstaw współrdzennych reprezentujących różne części mowy, np. rżiszcze, rżaniszcze.

Materiały gwarowe stanowiące podstawę map są uzyskiwane w terenie metodą od znaczenia do słowa i informują o terytorialnym rozmieszczeniu nazw jednego i tego samego desygnat (którym może być rzecz, czynność, cecha, zjawisko lub relacja), a także o morfemach rdzennych, formantach i sposobie derywacji. Ten typ map występuje najczęściej: 6) LSł 191 'wielki niedźwiedź’; 7) LSł 186 'wilczy ogon, ślad, futro'; 8) LSł 11 'gęsty las'; 9) LSł 12 'gęste zarośla, chruśniak'; 11) LSł 14 por. mapy nominatywne; 15) LSł 608 'szron’; 16) LSł 91 'kora brzozy'; 17) LSł 215 'kretowisko'; 18) LSł 28 'las rosnący nad brzegami rzek, jezior'; 19) Sł 6 'zagajnik, lasek z przewagą drzew jednego gatunku'; 20) LSł 189 Mapy: 'niedźwiedzica' + trzy dublety; 22) LSł 190 'niedźwiadek'; 24) LSł 16 'mały las, rzadki'; 25) LSł 34 'martwy las z drzewami zasuszonymi na pniu'; 26) LSł 34 por. mapy nominatywne; 27) LSł 213 'futro, skóra tchórza' (adj. possessivus); 28) LSł 20 'młody las z drzewami różnych gatunków'; 29) LSł 183 'niewielki wilk' (demin.); 32) LSł 102 'polana w lesie' + LSł 103 'odkryte miejsce w lesie'; 33) LSł 10 'rzadki las'.

6. Mapy motywacyjne - (2 mapy) przedstawiają podział terytorialny wyznaczony przez zasięgi nazw desygnatu pogrupowanych według wspólnej cechy. Taką cechą może być kształt, kolor, funkcja, relacja, proces, ocena, jakość i inne. Metodę motywacyjną zastosowano do opracowania mapy nr 5) LSł 15 'las chory, niski, krzywy, nie nadający się na budulec' oraz mapy nr 11) LSł 14 'las zdrowy, wysoki, prosty, nadający się na budulec'. W legendzie tych map wymienione są tylko wyróżnione przez nazwy cechy desygnatu. Przyporządkowane im znaki pokazują więc zasięgi nie pojedynczych, ale pogrupowanych nazw niezależnie od etymologii, jeśli łączy je któraś ze wskazanych cech. W rezultacie otrzymujemy inny, bardzo ważny typ podziału badanego terenu, rzucający nowe światło na procesy historyczne. Ta forma interpretacji geograficznej materiału językowego sprawia, że autor mapy musi wszystkie dane przenieść do komentarza. Komentarz odautorski, nie licząc pozostałych jego części, zajął autorce mapy 5) dwie i ćwierć strony, a autorce mapy 11) prawie stronę. Ten typ map nie ma w Polsce tradycji, więc warto bliżej zapoznać się z ich objaśnieniem. Mapa wskazuje, że nominacja dokonywała się przede wszystkim na tych obszarach, na których rozpowszechnione są lasy. Podstawą nominacji lasu chorego jest 6 głównych cech: 1. jakość, np. les: kri'voj, kri'vulja, gni'toj; 2. miejsce: bo'totnik, o'polica, sotonča'kovyj les; 3. ocena: chu'doj, nestroe'voj les, pto'xoj; 4. podobieństwo: tup'to; 5. proces: va'lëžnik; 6. funkcja: drovja'nik.

Mapowane są nazwy zarówno syntetyczne, jak i analityczne (występujące bardzo licznie), z wyjątkiem tych, które odnoszą się do leksyki profesjonalnej, do 
innych obiektów lub tych, których motywacja stała się już nieczytelna. Najczęściej tworzone były ze względu na funkcję. Nazwa las bez przydawki potraktowana została jako brak nazwy. W różnych gwarach motywacja tych samych nazw nie zawsze jest taka sama. Nie zawsze wiadomo, czy o powstaniu nazwy decydowała funkcja, czy np. jakość. Cecha jakości była również bardzo częstą motywacją powstawania nowych jednostek leksykalnych, co nie dziwi, gdyż na kształtowanie się dominanty znaczeniowej nazw wpływa wiele czynników.

Druga mapa motywacyjna ( $\mathrm{nr}$ 11) opracowana jest w ten sam sposób. W legendzie wymienione są cechy desygnatu będące podstawą nominacji: 1. jakość, np. prja'moj les; 2. ocena: deło'voj les; 3. podobieństwo: le'sina; 4. relacja: boro'vina; 5. funkcja: stroe'voj les. Materiał nazwowy jest wyeksponowany w indeksach (napisowym i liczbowym). Komentarz - zajmujący półtorej strony - informuje, że zarówno liczba nazw, jak i cech będących ich osnową jest - w porównaniu z mapą poprzednią - bardzo uboga. W nominacji „zdrowego” lasu dominuje aspekt kognitywno-gramatyczny. Bardziej różnicowane nazwowo jest to, co nie w normie.

7. Mapy nominacyjne - (2 mapy) ukazujące różnice w sposobach nazywania desygnatów należących do świata zewnętrznego. Mapy: 12) LSł 14 'las zdrowy, wysoki, prosty, nadający się na budulec'; 26) LSł 34 'las martwy z drzewami zasuszonymi na pniu'.

Pierwsza $z$ tych map jest wariantem omówionej wyżej mapy motywacyjnej. Jej treścią są zasięgi łącznie traktowanych: derywatów (występujących często), kompozycji (bardzo rzadko) i nazw opisowych (bardzo często). W polskich publikacjach atlasowych ten typ zróżnicowania geograficznego nie był dotychczas brany pod uwagę. Mapa druga ma tę samą legendę, ale obraz jej jest inny, ponieważ inne są proporcje pomiędzy typami nominacji lasu martwego i lasu zdrowego.

8. Mapy historyczno-lingwistyczne (leksykalne, leksykalnosłowotwórcze, semantyczne) mają pokazać dynamikę zmian w historycznym rozwoju leksyki. Ich opracowanie będzie możliwe na podstawie materiałów zebranych w przeszłości.

9. Mapy syntetyczne izoglosowe przewidywane są jako uogólnienie materiałów zawartych w poszczególnych tomach.

10. Mapa podziałów dialektalnych języka rosyjskiego zostanie opracowana na podstawie danych $\mathrm{z}$ zakresu leksyki i słowotwórstwa.

11. Mapy pomocnicze historyczno-archeologiczne.

Bardzo ciekawym eksperymentem w kartografii leksyki są zamieszczone w tomie próbnym dwa dodatkowe niepełne warianty mapy nazw niedźwiedzicy. Jeden z nich pokazuje zasięgi tylko dwóch nazw: ved'medica i med'vedica, drugi zasięgi sufiksów -icha i -ica w nazwach niedźwiedzicy. Dzięki technice kompute- 
rowej łatwiej daje się uprościć skomplikowana treść mapy przez przedstawienie jej uzasadnionych merytorycznie fragmentów na kilku odrębnych mapach. Innym eksperymentem, znanym $\mathrm{z}$ wcześniejszych doświadczeń, jest mapowanie samych rdzeni (mapa 23, L 379 'drobna ryba' - nazwa ogólna), których zasięgi dla historii języka, a zwłaszcza dla etnogenezy niezwykle ważne, ponieważ sięgają najgłębiej w przeszłość. Wszystkie próby kartograficzne zmierzają do możliwie najpełniejszej ekspozycji badanych zjawisk językowych przy jednoczesnym zachowaniu możliwie największej przejrzystości mapy, ułatwiającej jej odczytanie i porównywanie $z$ innymi kartogramami.

\section{PROGRAM ZBIERANIA MATERIAEÓW DO ATLASU LEKSYKALNEGO ROSYJSKICH GWAR LUDOWYCH}

Program badań i wszystko, co się z nim bezpośrednio wiąże: struktura kwestionariusza, wyodrębnienie tematów głównych i mniejszych grup tematycznych, forma pytań, materiały przykładowe i poprzedzająca każdy rozdział instrukcja, jest szczególnie cennym wzorcem dla tych środowisk, które dziś jeszcze prowadzą badania gwaroznawcze. Dialektologom rosyjskim, podobnie jak zespołowi zajmującemu się opracowywaniem słownictwa w regionie północno-wschodniopolskim, pomagali w bardzo dużym zakresie nieprofesjonaliści, w których kręgu byli także nauczyciele szkolni, studenci, młodzież starszych klas ogólnokształcących i krajoznawcy, będący nie tylko znawcami, ale i miłośnikami kultury badanych regionów. Uwagi podawane przed każdym głównym rozdziałem będą dla nas lekturą niezwykle pożyteczną.

Do programu badań terenowych włączono ponad 5000 pytań leksykalnych, to jest siedem razy więcej niż w OLA. Oczekuje się, że tak wielka liczba pytań zapewni możliwość wykrycia systemowych powiązań w leksyce gwarowej.

Numerację podaną w kwestionariuszu uzupełniają praktycznie częste pytania zwielokrotnione pod tym samym numerem, np. tradycyjne wypieki na wszystkie kolejne święta, obrzędy kościelne takie jak np. chrzciny i zwyczaje świeckie, jak pierwszy na wiosnę wypas bydła na polu (L 5 181). Kwestionariusz do działu budownictwo ma zupełnie inną formę. Pod jednym numerem pytania kryją się np. pytania o nazwy wszystkich desygnatów związanych $\mathrm{z}$ domem mieszkalnym. Dla ułatwienia autorzy tego działu wprowadzili litery wskazujące na części domu wyodrębniane nazwowo we wcześniejszych źródłach. Jest to dział bardzo trudny do badań, ale i o innych tematach można powiedzieć to samo. Do pozyskiwania w eksploracji terenowej ginących nazw $\mathrm{i}$ ich znaczeń potrzebna jest odpowiednia wiedza, a do jej poszerzenia z pewnością przyczynia się podstawowa literatura, zamieszczona po uwagach wstępnych do niektórych tematów. 
Doświadczenie uczy jednak, że nawet najlepsza instrukcja nie ustrzeże przed niepełnym zebraniem informacji. Dlatego tak ważne są spotkania bezpośrednie z eksploratorami. Dla rosyjskiej grupy eksploratorów T. I. Wendina od lat prowadzi specjalne seminarium.

Za podstawę opracowania kwestionariusza przyjęto kryterium znajomości realiów tak z zakresu tradycyjnej kultury materialnej, jak i duchowej. Zamieszczono w nim 7 głównych działów kultury. W obrębie głównych tematów wyodrębniane są węższe kręgi tematyczne, z których większa część będzie opracowana w oddzielnych tomach. Pytania są formułowane od słowa do znaczenia i na odwrót, dzięki czemu możliwe będzie ustalenie powiązań strukturalnosemantycznych i różnic derywacyjnych między słowami gwarowymi.

Tworząc mikropola leksykalno-semantyczne, w kwestionariuszu brano pod uwagę zarówno cechy dyferencjalne, jak i integralne, co we Wstępie pokazane jest na przykładzie leksykalno-semantycznej grupy (LSG) 'deszcz', w której uwzględniono takie cechy jak: intensywność, czas trwania, rozmiar opadów, ich liczbę, temperaturę $\mathrm{i}$ inne. W rezultacie takiej analizy sformułowano pytania o nazwy następujących desygnatów: 1) 'niewielki, krótkotrwały deszcz', 2) 'deszcz długotrwały', 3) 'drobny deszcz', 4) 'ciepły, grzybowy deszcz', 5) 'ulewny deszcz, ulewa’, 6) 'deszcz ze śniegiem’, 7) 'drobny, czysty’ (o deszczu), 8) 'iść' (o deszczu), 9) 'pokropywać', 10) 'mżyć', 11) 'lać', 12) 'deszczowy', 13) 'brak deszczu'.

Systemowe podejście do języka zakłada badanie tych leksykalno-semantycznych grup słów, które połączone są jakąkolwiek cechą, czego konsekwencją jest konieczność przedstawiania w Atlasie nie tylko nazw, ale i ich znaczeń, a także cech sygnalizujących rozróżnienia innego typu (np. rodzaj, liczba, aspekt, archaizm, neologizm itp.).

\section{PRZYRODA}

Uwagi wstępne. Stanowią instrukcję dla całego rozdziału kwestionariusza, ale łączę je z konkretnymi działami pytań. Są one interesujące metodologicznie. Numery pytań poprzedzone są sygnaturami sygnalizującymi przewidywany typ mapy. Po definicji lub nazwie desygnatu z sygnaturą L (Leksyka) lub Sł (Słowotwórstwo) przytaczane są nazwy synonimiczne, wyekscerpowane z różnorodnych, ustalonych źródeł dla ułatwienia eksploracji w terenie. W pytaniach z sygnaturą Sm (Semantyka) wymieniane są znaczenia słów znane z wcześniejszych opracowań. W nawiasach okrągłych podawane są dwie liczby połączone znakiem symbolizującym dodawanie. Pierwsza oznacza pytania leksykalne, słowotwórcze lub leksykalno-słowotwórcze, druga - mniejsza - pytania semantyczne. Podano je rozłącznie, aby pokazać proporcje liczbowe między onomazjologicznym a semazjologicznym typem badań. 
1. Świat roślinny $(160+16)$. Pożądane jest, aby rozmowę z informatorem zaczynać od pytań typu: Jakie drzewa (trawy, grzyby, jagody) znacie? ... rosna w waszej miejscowości? Z jakimi drzewami ... zwiazujecie określone cechy, wierzenia, obrzędy?

2. Świat zwierzęcy $(205+6)$. Rozmowę należy zaczynać także od pytań ogólnych: Jakie znane są tutaj zwierzęta dzikie, domowe, ptaki, ryby, owady? Pytać o formy lp i mn. (cielę - cielęta), o formy deminutywne i augmentatywne, o formy ekspresywne, nacechowane pozytywnie i negatywnie, o nazwy samic, młodych zwierząt, wydawanych głosów, przywoływań. Czy na nazwy ryb ma wpływ ich rozmiar, czas połowu? ...

3. Krajobraz a) gleba, ziemia, b) ukształtowanie powierzchni, c) wodozbiór $(105+37)$

4. Meteorologia, astronomia, kalendarz $(121+13)$. Części doby $(15+4)$.

\section{CZŁOWIEK}

1. Anatomia $(97+12)$.

2. Cechy fizyczne, cechy osobowości, stosunki społeczne: Powierzchowność w związku z cechami fizycznymi, wzrostem, stanem zdrowia, skłonnościami i przyzwyczajeniami $(81+5)$. Charakterystyka osobowości i zachowywania się człowieka ze względu na stan emocjonalny, zdolności intelektualne i stosunek do norm moralnych $(92+3)$. Charakterystyka człowieka, ze względu na jego stosunek do pracy i własności. Życie społeczne starej wsi $(46+4)$.

3. Medycyna ludowa: Choroby $(113+8)$. Lekarze i lekarstwa (10). Lekarstwa ludowe. (9). Higiena (10).

4. Rodzina, stosunki rodzinne $(260+14)$

5. Tradycyjna ludowa kultura duchowa: Demonologia $(46+4)$. Magia, czarodziejstwo $(35+2)$. Mitologizacja zwierząt i ptaków $(5+4)$. Kalendarz ludowy i obrzędowość kalendarzowa (94). Obrzędy związane z chrztem (41). Obrzędy weselne $(73+5)$. Obrzędy rekruckie (6). Obrzędy pogrzebowe i wypominki $(65+1)$. Zabawy, tańce, folklor $(33+1)$. Etykieta ludowa (85).

\section{PRACA, DZIAŁALNOSĆ}

6. Rolnictwo: Kultury zbożowe. Procesy związane $z$ ich uprawą i obróbką $(239+13)$. Rośliny strączkowe (groch, bób, fasola, wyka, soczewica) (23). Kultury techniczne i arbuzowe (23). Procesy związane z ich uprawą i obróbką (84+1?).

7. Ogrodnictwo (75). Płody korzeniowe (23). Warzywa (ogórki, kabaczki, bakłażany, pomidory, papryka) (18). Kultury cebulowe (cebula, czosnek) (16). Krzyżowe (kapusta) (17). Przyprawy korzenne (koper, tymianek, anyż, mięta) (6). 
8. Sadownictwo (53).

9. Hodowla: Zwierzęta hodowlane (wiadomości ogólne) (10). Duże bydło rogate $(5+2)$. Konie $(38+2)$. Owce, kozy i inne małe zwierzęta domowe $(44+5)$. Pasienie bydła $(42+6)$. Postronki, pęta $i$ inne (7). Ubój bydła ... (29). Choroby zwierząt domowych (6). Zwierzęta domowe (17).

10. Drobiarstwo $(138+3)$.

11. Pszczelarstwo $(45+7)$.

12. Obróbka lnu, przędzenie, tkactwo: Nazwy lnu i konopi (12). Zbiór roślin włóknistych (12). Obróbka włókna lnu i konopi (19+3). Przędzenie (22). Motanie (6). Snucie. Przygotowanie przędzy do tkania (11). Tkactwo?

13. Rzemiosła: Ciesielstwo, stolarstwo $(44+6)$. Kowalstwo $(20+2)$. Garncarstwo (13), Folowanie (22).

14. Rybołówstwo: Typy narzędzi, przyrządy rybackie i ich części $(62+2)$. Przyrządy: haczykowe (19), saczkowe $(4+1)$, plecione $(2+1)$, kłujące $(1+1)$.

15. Myślistwo (39+1).

\section{KULTURA MATERIALNA}

16. Budownictwo wiejskie: Wiejskie zabudowania $(17+1)$. Myśliwskie, przemysłowe i inne budynki poza osiedlem (6). Dom mieszkalny i jego części $(4+1)$. Meble stabilne (30). Ogrzewanie domu, piec (34). Części pieca (ruskiego) $(80+32)$. Strych i piwnice. Pomieszczenia i przybudówki należące do domu mieszkalnego (54). Zabudowania podwórzowe (24). Inne budynki gospodarcze, w większości nie związane z mieszkaniem $(60+19)$. Ogrodzenia $(40+7)$. Bramy i furtki (13). Zapory i zamki do drzwi i bram $(17+6)$. Technika słupowa w budownictwie $(12+3)$. Domy i budynki plecione (6). Domy i budynki z fabrykatów glinianych (10). Domy $z$ innych materiałów $(41+9)$. Prace wykończeniowe $(21+1)$. Inne materiały budowlane $(35+3)$. Różnorodna terminologia $\mathrm{z}$ zakresu budownictwa $(22+4)$.

17. Sprzęty domowe: Naczynia (60+7). Sprzęty kuchenne $(45+1)$. Meble ruchome (20). Kosze $(12+11)$. Worki, torby (7).

18. Wiejska odzież, obuwie, nakrycia głowy, rękawice, ozdoby: Ogólne nazwy odzieży, jej charakterystyka jakościowa, przeznaczenie: wierzchnia, męska i żeńska; części odzieży $(58+1)$. Odzież żeńska (43+5). Odzież męska (18+2). Żeńskie nakrycia głowy (9+4). Męskie nakrycia głowy (4). Rękawice (15). Żeńskie ozdoby $(22+1)$. Obuwie, pończochy, skarpety $(22+1)$.

\section{POŻYWIENIE}

19. Pokarmy, napoje i ich przygotowanie $(245+5)$. 


\section{DROGI, ŚRODKI TRANSPORTU}

20. Drogi lądowe (44+3). Srodki komunikacji, transport (91 ). Uprząż (45) 21. Transport wodny (103).

\section{LEKSYKA INNYCH KRĘGOOW TEMATYCZNYCH}

Rzeczowniki (30+9 pytań). Przymiotniki $(43+6)$. Czasowniki $(37+12)$. Przysłówki (37).

\section{SEMANTYKA I KOMPLEKSY TERENOWE (796 PYTAŃ SM)}

Główne cele: a) zbadanie leksyki na pograniczach ukraińskim i białoruskim, b) zbadanie leksyki rozprzestrzenionej w regionach: północnym, zachodnim, południowym, wschodnim i centralnym, c) zbadanie semantyki słów wieloznacznych, d) zbadanie słowotwórstwa prefiksalnego, szczególnie w czasownikach, e) zachowanie się w gwarach współczesnej dawnej leksyki. Należy: zapisywać warianty słów będące w użyciu, ich akcent, znaczenie, przykłady ilustracyjne; pamiętać o kwalifikatorach typu rzadkie, nowe, archaiczne, o potrzebnych rysunkach i fotografiach, pytać o środowisko używające danego słowa.

Każde nowe osiągnięcie - zwłaszcza jeśli jest tak imponującą, nowatorską realizacją choćby części wielkiego zamierzenia, jak tom próbny Atlasu leksykalnego rosyjskich gwar ludowych, musi budzić nie tylko zainteresowanie, ale także głęboki podziw i uznanie dla inicjatorów, redaktorów, współautorów, eksploratorów, organizatorów, a przede wszystkim dla redaktora głównego, którego trud jest podwójny, gdyż poza wykonywaniem konkretnych zadań ciąży na nim odpowiedzialność za całokształt tego wiekopomnego dzieła. Dziękujemy wszystkim za ten wspaniały, niedościgły dla nas wzorzec i życzymy wytrwałości, a także sił do dalszej pracy, które będą potrzebne jeszcze na wiele, wiele lat. 